\title{
SMEs' Digital Transformation Facilitated by COVID-19
}

\author{
Ramona Rupeika-Apoga ${ }^{1 *}$, Kristine Petrovska$^{1}$ and Larisa Bule ${ }^{1}$ \\ 1 University of Latvia; rr@lu.lv \\ * Correspondence: rr@lu.lv
}

\begin{abstract}
The COVID-19 crisis has emphasized the importance of digital transformation of SMEs and has served as an accelerator. Digital transformation empowers SMEs to rethink the way they make decisions and apply technology in meaningful and sustainable ways. The purpose of this study is to explore the role of digital transformation, fostered by COVID-19, and its potential contribution to the economic sustainability of SMEs. We consider that a company will be more economically sustainable if it is more deeply integrated into the supply chain, has a more diverse customer base and higher revenues. This paper examines a new conceptual framework designed on resourcebased theory perspectives by using a survey data of 246 SMEs in Latvia and employing mediation analysis. The main findings of the study are that digital orientation and digital capability have direct positive effects on digital transformation; higher levels of digital orientation and capability, mediated by digital transformation, lead to higher revenue; as well as a more complex business model in the case of digital orientation; which generally contributes to greater economic sustainability of SMEs. Even if we cannot confirm that higher digital capability, mediated by digital transformation, leads to a more complex business model, we found statistically significant direct effects from digital capability to digital transformation and from digital transformation to business model complexity. These findings can be useful for policymakers, managers and practitioners to clarify how digital orientation, digital capability intermediated through digital transformation affect economic sustainability of SMEs.
\end{abstract}

Keywords: Digital Transformation; SME; Digital Orientation; Digital Capability; Economic Sustainability; Mediation Analysis

\section{Introduction}

Confidence in digital transformation being a crucial element of a successful development of companies and economies is quite wide-spread amongst policymakers [1-4] and the academic community [5-11]. COVID-19 has fuelled digital transformation across industries by offering companies the opportunity to change their practices fundamentally and to alter strategic vision based on long-term growth and value creation for all stakeholders. At the same time, Covid-19 is a new, unexplored framework that has spurred the digital transformation of companies, accelerating overall digital adoption by three to seven years in a matter of months [12]. Since the pandemic has forced companies to remove many of the obstacles that once stood in their way to digital adoption, such as network security that allows employees to work remotely, companies will find it much easier to work remotely in the future. Companies have already made key investments to help them protect their digital security and have created a technology infrastructure that allows employees to work from their home office. Therefore, given the growing pressure on global resources and the urgent need to reduce emissions, digital transformation can help companies transform in a sustainable manner. Digital transformation opens new horizons for companies combining digital and environmental goals. In this study, we apply the concept of economic sustainability, which refers to practices that support long-term economic growth without negatively impacting the social, environmental and cultural aspects of a community $[13,14]$. Companies can integrate sustainability strategies across 
many facets of their digital transformation roadmaps, also data sharing and tracking platforms can reduce environmental impacts before they enhance [14]. Companies can seize the current crisis as an opportunity to expand their competitive advantage and deliver long-term value by deepening the integration of sustainable practices into their business and value chain as digital transformation continues [15]. We consider that a company will be more economically sustainable if it is more deeply integrated into the supply chain, has a more diverse customer base and stable revenues. The economic activity of Latvian enterprises is generally considered sustainable in terms of low emissions of greenhouse gases (so called brown sectors are insignificant). Latvian economic growth is not dependent on environmentally destructive forms of activity, especially fossil fuels like coal, oil and gas. The total volume of GHG emissions per capita in Latvia is among the most modest levels in the European countries [16].

But what is going on in the real world, are companies striving to transform? There is still a lot of work ahead, according to the OECD study on digital transformation [1], as big data, e-orders, supplier- customer management and e-commerce are still underdeveloped. Similar results are revealed by other surveys $[2,3,14,15]$. Large companies are better positioned to take advantage of new technologies and turn them into smart and sustainable companies [16], but what about small and medium-sized enterprises that form the backbone of any economy? SMEs are not prompt enough in digital transformation, and the smaller the company, the lower the probability of introducing new digital solutions [3]. Recent EU surveys show that in 2019 76\% of Western European SMEs determined digitalization as a priority, the most common activities were electronic invoicing (60\%), application of software to facilitate collaboration (60\%) and process monitoring (53\%) [19]. At the same time, a survey carried out by SEB Bank in December 2019 clearly showed that SMEs in the Baltic States occasionally refrain from digitalizing their activities, given that a quarter of respondents sell goods or services on the Internet. $47 \%$ of SMEs in Latvia and $51 \%$ in Lithuania recognized digitization as a substantial premise for business development, while in Estonia this indicator is higher- 55\% [20]. The aforementioned surveys describe the current state of digitalization and expectations of SMEs before the COVID-19 outbreak, but it is necessary to find out how the situation has changed due to the pandemic. COVID-19 certainly made companies relocate their operations online and enforce smart working solutions to continue business during lockdowns and mitigate disruptions in supply. Global business data indicates that up to $70 \%$ of SMEs have increased their use of digital technology due to COVID-19 [1].

The process of digital transformation of companies obviously has been speeded by COVID-19. In order to prevent themselves from failure companies can no longer postpone business digitalization, even if they are still hesitant. Overall digital transformation of SMEs can take place in two alternative scenarios: 1 ) a chaotic scenario turning non-digital companies into minimally qualified and dependent end users of ICT products and services, or 2) a smart scenario that makes companies complete the process of sustainable digital transformation. In this sense, digital transformation has the power to support SMEs' transformation to economically sustainable companies able to maintain and expand their market position in a continuously digitalized economy. However, digital transformation is far more than being online. Digital transformation is a paradigm shift that changes the entire business model of companies and their revenue streams and that must be accompanied by an appropriate ecosystem, focused on digital strategy and digital skills.

Given the universal importance of SMEs and their role as backbone of any economy, the purpose of this study is to explore the role of digital transformation, fostered by COVID-19, and its potential contribution to the economic sustainability of SMEs.

This research is based on the data of an online survey carried out during February/March 2021 amongst owners and managers of 433 companies registered in Latvia, when there was a state of emergency in Latvia. The state of emergency began on November 6, 2020 and ended on April 7, 2021. This is a period when restrictions to contain the spread of coronavirus included remote work excluding essential workers and jobs that 
cannot be carried out remotely. Companies in many sectors, such as tourism, accommodation and catering, water and air transport, retail, and others, were under pressure, and going digital was the only possible solution for many of them to survive. Conducting a survey where companies were constrained to provide services in the traditional way for several months was especially important to understand the needs of companies to start or facilitate their digital transformation. To collect information about how SMEs manage their resources, survey questions were designed from two perspectives of resource-based theory: resource orchestration and dynamic managerial capabilities. To examine the role of digital transformation during COVID-19 from a resource-based theory perspectives, the survey data was narrowed down to responses from 246 managers of SMEs. In this survey, we used a 7-point Likert scale. In our research, we empirically investigate the digital transformation journey of SMEs towards economic sustainability in Latvia during COVID-19.

Mediation analysis has become a popular method answering whether the relationship between two variables is explained by a third intermediate variable. To achieve the purpose of this study, we apply mediation analysis by using Hayes PROCESS v4.0 module [21]. This study used the two-step approach; that is, the analysis of the measurement model first, followed by the mediation model. We investigate the mediating effect of digital transformation on revenue and business model complexity as two dimensions of the core business model areas, which together help measure a company's economic sustainability.

While academics focus on both digitalization and sustainability, our understanding of the role of digital transformation in the economic sustainability of SMEs remains surprisingly incomplete. This is remarkable because digital transformation provides SMEs with strategic directions to design and implement specific digital transformation strategies and select appropriate digitalization initiatives to ensure their sustainable journey. A number of academic studies have confirmed that digital transformation is critical for the modern economy, as it has a wide range of consequences for business [6,22-26]. Leveraging digital capabilities and orientation by focusing on improved service delivery and customer integration can add value to the products and services they offer while increasing profitability over the long term [27-29]. While the significant effect of digital transformation seems clear, the nature of this effect is unclear, and scientists are increasingly expressing concern about the productivity of digital investments and their impact on the sustainability of companies [26,30].

We argue that digital orientation and digital capability mediated by digital transformation are driving different and new ways of managerial and organizational alignment that have been overlooked in previous strategic studies and their combinations [31-34]. Previous literature has examined the relationship between digital orientation and digital capability on digital innovation, but no evidence has been found for their relationship to digital transformation. In accordance with Kindermann et al. [31] the digital orientation idea aids in defining the types of digital resources that must be aligned in order for a company to develop a foundation for improved performance. While Khin and Ho [32] found that digital orientation and capability have a significant effect on digital innovation. Ardito et al. [34] found that digital orientation has a positive direct effect on product and process innovation performance. However, previous research in this area does not fully reflect the increased functional role of digital orientation and digital capability mediated by digital transformation for the sustainability of SMEs. The current empirical research on digital transformation is largely based on case studies, limited question and answer surveys, or historical data on technology investment, with no generalized or longitudinal studies. Thus, deepening knowledge of the relationship between the driving forces and the impact of digital transformation on the sustainability of SMEs enables longitudinal research that is vital for stakeholders, including SMEs, academia and policymakers. To the authors' knowledge, there are no studies that investigate the mediating impact of digital transformation of SMEs on the relationship between digital orientation and capability on revenue and business model complexity. In this study, we argue that mediating the 
contribution of digital transformation transfers digital orientation and digital capability into higher performance.

COVID-19 has recently triggered another crisis; thus, scientists, entrepreneurs and people in the research industry are faced with an entirely new global quest with economic and social impact [35]. Thus, this study complements the literature on digital transformation in the context of COVID-19 with a meaningful empirical relationship between digital transformation and sustainability of SMEs.

Summing up, we can say that our contribution to academic literature and socio-political debate is fourfold. First, we propose a new conceptual framework highlighting the link of digital transformation to both drivers and performance, boosted by COVID-19. Verification of our conceptual framework provides empirical evidence for the relationship between driving factors and the influence of digital transformation on economic sustainability of SMEs during COVID-19, thereby also filling a gap in the literature.

Second, we believe our study will expand the literature on digital transformation by deepening knowledge about how the positive impact of digital transformation on the sustainability of SMEs has been amplified, in particular, by identifying the relationships between digital orientation and digital capability mediated by digital transformation on the economic sustainability of SMEs.

Third, this study adopts such new terms as digital orientation and digital capability, which could be expanded and become key constructs in the concept of digital transformation. The concepts of digital orientation and digital capability have been built on two specific perspectives of resource-based theory: resource orchestration and dynamic managerial capabilities theories in relation to the need for digital transformation in resource management.

Fourth, the findings of this study can be useful also internationally. Latvia is a small open economy, it might not necessarily appear of particular importance on a global scale, yet, in the context of SMEs and their struggle for digital transformation, the small size of an economy is not necessarily a disadvantage.

We find that digital capability and digital orientation have direct positive effects on digital transformation; higher levels of digital orientation and capability, mediated by digital transformation, lead to higher revenue; as well as a more complex business model in the case of digital orientation. Even if we cannot confirm that higher digital capability, mediated by digital transformation, leads to a more complex business model, we found statistically significant direct effects from digital capability to digital transformation and from digital transformation to business model complexity. In addition, we found that digital orientation and digital capability have a direct positive effect on revenue, while no direct positive effect of digital transformation on revenue has been confirmed. This allows us to conclude that higher levels of digital orientation and capability, mediated by digital transformation, contribute to greater economic sustain-ability of SMEs.

The structure of this paper is as follows. The next section, Section 2, discusses the theoretical background and hypotheses. Section 3 focuses on the data and methodology. The results of data analysis for measurement model and structural model are provided in Section 4, as well as the insights into the hypotheses confirmed. Section 5 emphases theoretical contributions and practical implications. Section 6 discusses the findings and concludes.

\section{Theoretical Background and Hypotheses}

To create a new concept, three requirements need to be taken into account: a characteristic, an appropriate measurement model, and evidence that the indicators measure the proposed concept [36]. We start with conceptualizing digital transformation on the basis of a review of existing literature.

Digital transformation makes companies consider a number of resource challenges. New and sometimes very significant investments in the company, employees and cus- 
tomers are demanded in the digital journey. Therefore, to explore the role of digital transformation during COVID-19, we rely on two specific perspectives of resource-based theory: resource orchestration and dynamic managerial capabilities approaches. The role of resource-based theory is to develop and maintain competitive advantage through the management of its resources and capabilities. Whereas, resource orchestration theory expands on the basis of resource theory and considers the actual role of the manager in the resource management process. The dynamic managerial capabilities (DMC) approach contends that companies need to constantly align, modify, and reconfigure their resources and capabilities in a dynamic and volatile environment to ensure sustained innovation and earnings above normal returns [37]. Both theories help us delve deeper into two aspects of digital transformation: resource management and management capabilities. Resource orchestration assumes that managers perform an active role in the development of capabilities and resources, thus building the combination of resources, capabilities and managerial foresight leading to various organizational outcomes [38,39]. While DMC embodies the importance of managerial intent, routines, and capabilities in influencing the restructuring of a company's resource base [38]. A company's resources include all assets, tangible and intangible, that the company controls and that are conducive to improving its efficiency and effectiveness. Competitive advantage is also an important concept that derives from $\mathrm{DMC}$, as a company has a sustainable competitive advantage when it implements a value creation strategy that is not pursued simultaneously by current or potential competitors. The resource orchestration and dynamic managerial capabilities perspectives are appropriate for investigating business transformation [31,40,41]. These perspectives are considered useful in theory because they explicitly address how entrepreneurial and managerial actions contribute to adapting and changing the resources, processes and structures that are required when a company engages in digital transformation through a coherent digital transformation strategy [42]. Thus, we develop a concept linking digital orientation and digital capabilities with digital transformation, applying the perspectives of resource orchestration and dynamic management capabilities [8,31-33,39,43].

\subsection{Digital Transformation}

Digital transformation begins with the process of transforming information from a physical format to a digital version known as digitization. Digitization can improve efficiency if digitized data is used to automate processes and make it more accessible, but digitization is not aimed at optimizing processes or data. Companies cannot embark on a digital journey if they didn't go through digitization first. The next step is to use digital technology to adopt the business model and provide new opportunities for generating income and creating value, this is called digitalization. It is the process of moving to a digital business [44]. Digitalization includes the process of adapting old business models to new technologies and unlocking the potential of digital technologies to collect data, identify patterns and make smarter business decisions [45,46]. However, digitalization improves rather than transforms the existing business process, transforming the process from a human-driven event to a software-driven event.

Finally, digital transformation is the integration of digital technology across all areas of the business, revolutionizing the way you work and deliver value to your customers. The entire business model change follows the process of digital transformation, and it needs to be supported by an ecosystem, dedicated digital strategy and digital skills. It's also a cultural change that requires organizations to continually challenge the status quo, experiment, and get comfortable with failure [47-49]. Digital transformation is a multidimensional phenomenon which implies the use and applications of a broad range of technologies for different purposes.

Since the onset of the COVID-19 pandemic, there has been a dramatic increase in the use of digital solutions and online commerce by SMEs. As the crisis continues, these changes will last for a long time, and the attraction of resources will be irreversible. The digitalization process has continued at a rapid pace in recent years, but SMEs are lagging in the transition, despite the potentially huge benefits [1]. Digital transformation is the 
cultural, organizational and operational change of a company through the phased and strategic integration of digital technologies, orientation and capabilities at all levels and all functions.

\subsection{Digital Orientation and Digital Transformation}

In the literature, digital orientation is proposed as a strategic company orientation focused on the changes brought about by digital technologies such as social networks, mobile applications, and digitized processes [8-11]. At the same time, digital transformation is inherently linked to strategic changes in the business model as a result of the implementation of digital technologies [22]. The nature of digital technology is fundamentally different from non-digital technology [12]. Digital orientation means a business that is more focused on the digital business market, including through the use of digital technologies.

Besides the aspects of technology, digital orientation also covers the strategy that fosters digital transformation and provides a competitive advantage. This view is consistent with research on strategic orientations such as the perspectives of resource orchestration and dynamic management capabilities. According to academic findings, the strategic orientation of companies explains the higher performance of the company because it shapes the way companies transform their businesses and modify resources [31,50]. Kindermann et al. (2020) concludes that one of digital orientation dimensions defines the digital technology scope as the set of digital technologies that allow the company to realize strategic growth [31]. Companies characterized as digitally oriented tend to implement digital technologies in all functional areas and embrace digital initiatives promptly through commitment and appropriate thinking [51]. The digital orientation has implications for the development and acquisition of new skills, competencies and knowledge, which are important resources that can facilitate the digital transformation [34]. Drawing on resource-based theory, digitally oriented companies in the context of innovation attain higher levels due to their broader vision and commitment to using new technologies to develop innovative products [32]. With the above rationale and literary support in mind, this current study argues that companies focused on digital orientation are more interested in digital transformation. Therefore, we hypothesize as follows:

H1. Digital orientation has a positive impact on the digital transformation of SMEs, fuelled by COVID-19.

\subsection{Digital Capability and Digital Transformation}

Digital transformation is enabled by technology - and due to the pandemic, it is happening faster than ever. The latest data shows that we have moved forward five years in digital adoption by consumers and businesses in just eight weeks [52], however, companies need the relevant digital capabilities for digital transformation. According to the theory of dynamic managerial capabilities, digital capability can be viewed as dynamic capability, described as the ability of companies to create new products and processes and to respond to market evolution [32]. Digital capability is characterized by technology affordances [13]. It includes the efforts of companies in development and maintenance of procedures that exploit human capital and knowledge assets to interact with a specific set of digital technologies [8]. Business performance is determined by the company's capabilities [53]. The concept of company capability is based on the flexibility and dynamic capabilities of the company, including its digital capability.

Digital capabilities are now a prerequisite for the sustainability of companies in the long term. However, many companies interested in digital transformation still do not know how to build their IT organizations and develop the tools and talents needed to manage digital information and build and maintain online services and automated processes. From the outset, most companies do not properly realize that many of the critical resources needed to facilitate digital transformation will not be available internally. While 
it is high time for many sectors to go digital, it can take years to develop the necessary capabilities internally. At the same time, seeking out digital capabilities from the outside is likely to be problematic, but in the long term, this approach can help companies meet the challenges of innovation and better competition online.

Development of capabilities necessary in different areas is one of the imperatives of digital transformation whereas the variety of capabilities depends on the specific sector and the specific needs of the company [54]. Digital capabilities have a positive impact on digital innovation and, as a result, on digital transformation [55].

Therefore, we hypothesize as follows:

H2. Digital capability has a positive effect on digital transformation of SMEs, fuelled by COVID-19.

\subsection{Digital transformation as a mediator of economic sustainability of SMEs}

A number of academic studies have confirmed that digital transformation is critical to the modern economy as it has a wide range of business implications [6,22-26]. It has been shown that embracing digital capabilities and orientation to improve service delivery and customer integration increases the value of the products and services they offer, while increasing the long-term profitability [27-29]. In addition, scientists noted the positive impact of digitalization on revenue growth, cost reduction, financial performance, and sustainability [56-59]. Digital transformation increasingly requires SMEs to strive to achieve environmental sustainability goals [56].

The sustainability concept is often broken into three core concepts: economic, environmental, and social. In this study, we apply the concept of economic sustainability, which refers to practices that support long-term economic growth without negatively impacting the social, environmental and cultural aspects of a community [13,14]. The economic dimension of a company's sustainable development can be defined as a business approach to creating long-term value, considering how the company operates in an ecological, social and economic environment. At the same time, digital transformation is a process that changes the entire business model and must be supported by an ecosystem, dedicated digital strategy and digital skills. When evaluating a business model, it is popular to use the business model canvas proposed by Osterwalder and Pigneur [60], which can be grouped into four main business areas: infrastructure, value proposition, customers, and financial viability. In this study, we explore two dimensions - customers and financial viability, as these dimensions play a special role in transforming the business model due to the growing importance of e-commerce. We consider that a company will be more economically sustainable if it is more deeply integrated into the supply chain, has a more diverse customer base and higher revenues. Several indicators can help measure a company's economic sustainability, with the most commonly used financial viability indicators such as revenue, net income, gross margin, working capital, etc $[14,43,61]$. In this study, we have selected revenue as the most appropriate for measuring the financial dimension of the economic sustainability of SMEs. First, it is one of three metrics, together with the number of employees and assets, to identify SMEs. Second, revenue is a subjective measure of how well a company can use its core business assets and make a profit. Third, revenue is the total amount of income received from the sale of goods or services related to the main activities of the company. Selling goods or services is the backbone of any company's business, while digital transformation has radically changed the way it is done. Khin and Ho [32] argued that digital orientation has a significant beneficial impact on digital innovation, while Yang et al. [62], stated that technological orientation has a positive impact on innovative products. A study conducted by Ardito et al. [34] shows that digital and environmental orientation impact product and process innovation. Based on Kindermann et al. [31] definition, the concept of digital orientation helps companies develop a foundation for improved performance by aligning the types of digital resources available to them. Therefore, we hypothesize as follows: 
H3. Digital transformation mediates the effect of digital orientation on revenue of SMEs, fuelled by COVID-19.

Additionally, Kindermann et al. [31] suggest that companies can overcome strategic challenges associated with the pervasiveness of digital technologies by adopting and maintaining a digital orientation. The business model perspective in the context of sustainability emphasizes the logic of creating value for the organization and its effects and potentially requires new forms of governance such as cooperatives, public-private partnerships or social business, thereby helping to move beyond narrow horizons [61]. At the same time, the non-financial aspect of the company's sustainability is focused on longterm success and quality aspects of the business. Typical non-financial performance indicators include measures that relate to business models, customer relationships, employees, operations, quality, cycle times, and an organization's supply chain. To measure the economic sustainability of SMEs from a client perspective, we chose the complexity of the business model. We do consider the fact that the company is more sustainable as it is deeper integrated within the supply chain and has a more diverse client base. The complexity of the business model, combined with revenue, helps to explore the mediating impact of digital transformation on the sustainability of the company as aspects of the business model: customers and financial viability.

Digital transformation changes a company's business model and provides opportunities to improve the value creation by transforming the way we do business [63]. Digital orientation has been shown to increase the value of the products and services a company offers, as well as her long-term profitability, by improving service delivery and customer integration [27-29]. Therefore, we hypothesize as follows:

H4. Digital transformation mediates the effect of digital orientation on business model complexity of SMEs, fuelled by COVID-19.

While the positive effect of digital transformation seems clear, the nature of this effect is unclear, and scientists are increasingly expressing concern about the productivity of digital investments and their impact on the sustainability of companies [26,30]. Real data and surveys show that the overall level of digital adaptation of SMEs $[1,3,4,64-66]$ is low, and SMEs lag significantly behind large companies. An obvious question arises: "Do SMEs believe in the potential of digital transformation and its impact on a company's sustainability?"

Sustainable development is built on the assumption that developing such strategies contributes to the company's longevity. The economic sustainability aspect determines if a company is implementing its business strategy successfully and can be reviewed to identify areas for improvement. Al-Ansary et al. [67] studied the mediating effect of product innovation on the relationship between performance and technology orientation as capability. Results of their research show that technology orientation influences the behavior and tendencies of SMEs in the Dubai market with regards to innovation, and that innovation mediates the relationship between technology orientation and business performance. Therefore, we hypothesize as follows:

H5. Digital transformation mediates the effect of digital capability on revenue of SMEs, fuelled by COVID-19.

Khin and Ho [32] identified the positive effect of digital orientation and digital capability on digital innovation, and the mediating effect of digital innovation on financial and non-financial performance affected by technology orientation and digital capability. Yasa et al. [33] research findings show that digital capability and digital innovation have a positive and significant effect on business performance, while digital innovation is able to mediate the effect of digital capabilities on business performance. Pham at al. [13] found 
that companies which put more emphasis on sustainable practices achieve better performance than those without such commitments. Zhang et al. [68] found that digital transformation of enterprises can help improve the resilience of an organization. Moreover, digital transformation mediated by both exploitative and explorative innovation increases the resilience of enterprises [68]. In their research, Youssef and Lebdaoui [69] have examined how digital orientation and digital capabilities translate into digital innovation and organizational performance, affirming that digital innovation is a mediating factor between digital transformation and organizational performance. Therefore, we hypothesize as follows:

H6. Digital transformation mediates the effect of digital capability on business model complexity of SMEs, fuelled by COVID-19.

\section{Methodology}

\subsection{Data Collection and Sample Characteristics}

To collect data to test our hypotheses, we needed to conduct a survey. The survey consisted of 17 statements identified after reviewing the literature on digital transformation in SMEs, and 5 company-specific questions related to the company size, revenue, business models, economic sector and respondent status/position in the company. The survey was carried out with the assistance of a consulting company mainly addressed to various professional associations of small and medium-sized businesses. In addition, the authors also used social networks such as LinkedIn @), Twitter @ and Facebook @; by oral personal meeting and by phone; and online communication with SMEs representatives. The questionnaire was online based and took place in February/March 2021. The answers were transformed using a 7-point Likert scale, which is the most reliable of the Likert Scales as it captures the best sentiment of the respondent. In addition, it provides better accuracy on the results and is incredibly useful for the researchers, as well as providing more data points for processing statistical information [18]. The resultant 433 sample participants were fairly balanced between micro-companies (44\%), small companies $(42 \%)$ and medium-sized ones (13\%). The sample consists only of SMEs who employ less than 250 employees and their yearly revenues are less than 50 million euro. The classification of Micro, Small and Medium-Sized Enterprises by size was based on the number of employees in the company in accordance with the applied methodology of the European Commission [70].

Generally, Latvian businesses are considered sustainable when it comes to greenhouse gas emissions. So called brown sectors (D, E, B and H, and in Latvia also A) take up $16 \%$ of total value added in 2019. Also looking at our sample, we see that SMEs considered in brown sectors take up a small amount of the total sample (see Table 1).

Table 1. Sustainability of Latvian economic sectors and research sample.

\begin{tabular}{|c|c|c|c|}
\hline & $\begin{array}{l}\text { Value } \\
\text { added, } \\
2019\end{array}$ & $\begin{array}{l}\text { Sample } \\
\text { distribu- } \\
\text { tion }\end{array}$ & $\begin{array}{l}\text { Carbon intensity of } \\
\text { sectors (all green- } \\
\text { house gasses), kg } \\
\text { per euro value } \\
\text { added, } 2019\end{array}$ \\
\hline Total & 100.0 & 100.0 & 0.459 \\
\hline A Agriculture, forestry and fishing & 4.6 & $14 \%$ & 2.927 \\
\hline B Mining and quarrying & 0.5 & $1 \%$ & 0.384 \\
\hline C Manufacturing & 12.2 & $13 \%$ & 0.437 \\
\hline D Electricity, gas & 1.7 & $2 \%$ & 4.757 \\
\hline
\end{tabular}


E Water supply; sewerage, waste management

F Construction

G Wholesale and retail trade

$\mathrm{H}$ Transportation and storage

I Accommodation and food service

J Information and communication

K Financial and insurance activities

L Real estate activities

M Professional, scientific and technical

$\mathrm{N}$ Administrative and support service

O Public administration and defence

Q Human health and social work

$\mathrm{R}$ Arts, entertainment and recreation

\begin{tabular}{|r|r|}
\hline $1 \%$ & 2.428 \\
\hline $8 \%$ & 0.147 \\
\hline $10 \%$ & 0.067 \\
\hline $3 \%$ & 1.772 \\
\hline $3 \%$ & 0.026 \\
\hline $7 \%$ & 0.008 \\
\hline $4 \%$ & 0.008 \\
\hline $1 \%$ & 0.038 \\
\hline $7 \%$ & 0.026 \\
\hline $2 \%$ & 0.077 \\
\hline $0 \%$ & 0.059 \\
\hline $5 \%$ & 0.020 \\
\hline $6 \%$ & 0.046 \\
\hline $3 \%$ & 0.024 \\
\hline $6 \%$ & 0.033 \\
\hline
\end{tabular}

T Activities of households as employers; undifferentiated goods- and ser-

vices

$6 \%$

Source: Bank of Latvia [71], authors' calculated

A business model is a broad concept that can be measured in many different ways. A complex business model addresses a potentially broader value proposition through one or more products and services [72]. Business to consumer (B2C), business to business (B2B), and business to government (B2G) are three common types of business models. The most popular among the surveyed SMEs is to use both B2B and B2C (38\% of SMEs), followed by B2B (25\%) and B2C (19\%). For micro-enterprises, B2C is the most popular business model; for small and medium-sized enterprises, it is B2B. This difference can be explained by different target audiences. For B2C companies, the target audience is a consumer, and for B2B companies, another company. The rise of B2B e-commerce solutions has changed the relationship between businesses and suppliers. As a product of the digital revolution, these companies sell products directly to other companies using e-commerce platforms, and exchange data and product or service updates. B2C has traditionally referred to shopping in malls, restaurants and commercials. However, digitalization has created an entirely new B2C business channel in the form of e-commerce or the sale of goods and services online.

To explore the role of digital transformation, enhanced by COVID-19, we draw on two specific perspectives of resource-based theory: resource orchestration and dynamic management capabilities, both of which focus on managerial behaviour. As a result, the survey data were narrowed down to responses of 246 managers of small and mediumsized enterprises registered in Latvia.

\subsection{Measures}

Following the literature review presented in Chapter 2, we designed our survey instrument. The measures are summarised in Table 2 . We measure digital orientation by the level of usage of big data, internet of things, artificial intelligence, robots (drones), and implementation of block chains. Digital capacity was measured by lack of skills to develop software and usage of software, lack of mathematical and analytical skills, and lack of website development skills, lack of digital project management skills, lack of data and database management skills, lack of digital strategy and leadership skills and lack of data 
entry and processing skills. A systematic analysis of the literature shows that the process of digital transformation is mainly studied in the context of three approaches, namely addressing drivers and objectives that trigger the digital journey, factors of success and implications $[73,74]$. Taking into consideration that the majority of Latvian SMEs are only close to or in the beginning of their digital journey, we've decided to consider the digital transformation from the point of view of its drivers and objectives proving that digital capabilities and orientation have a positive impact on triggering digital transformation per se. The range of drivers and objectives provided in scientific literature is extremely wide and differs depending on the industry $[73,74]$. Our sample is multi-sectoral, therefore we tried to provide a universal combination of factors triggering digital transformation in different industries. Digital transformation was measured by optimization of business processes, procedures and costs; aspiration to improve or change business model; direct contact with customers/suppliers/better customer journey; safeguarding the future of the company / its expansion; creation of new jobs/stronger internalization. In this paper we refer to the economic sustainability of SMEs as the ability to create long-term value as measured by revenue and business model complexity as indicators of business models. SMEs' revenue was measured by annual revenue, and the complexity of a business model was measured by the degree to which the business was integrated into the supply chain (higher integration and more complex business model received a score of " 6 "). The scores of business model were authors' assigned based on answers on what types of clients do SMEs have, score of "1" was assigned to B2C, score of "2" was assigned to B2C, B2G business model, score of "3" - B2G, score of " 4 " - B2G, B2B, score of " 5 " B2B, score of "6", B2B, B2C. None of the SME's had a business model of B2C, B2G, B2B.

Table 2. Measurement items.

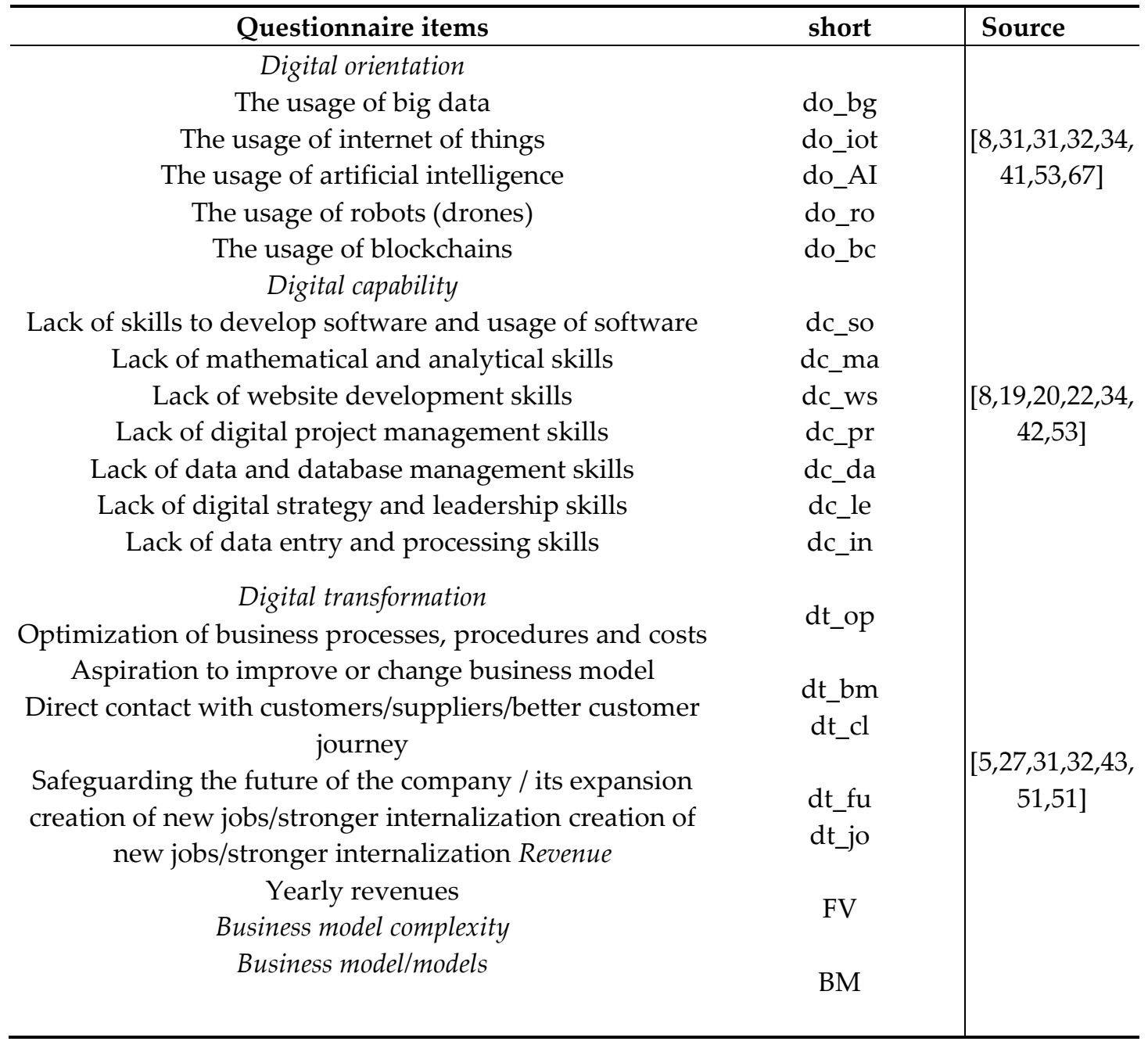

Source: authors' developed 


\section{Results}

To screen data, profile respondent firms, and run statistical tests, SPSS Version 26 was used. Mediation analysis was done using Hayes PROCESS v4.0 module [21]. Mediation analysis by using PROCESS has become more popular in psychological, socioeconomic studies. This tool allows free-access pre-coded module to be used in data modelling and is user friendly. A. Hayes developed an observed variable OLS and logistic regression path analysis tool called Process. Direct effects and indirect effects can be estimated in models with a single mediator and multiple mediators (parallel and serial), two and three way interactions in mediation models, as well as indirect effects in models with a single mediator (in our case - digital transformation). Additionally, we used the boot-strapping method to test the significance of the effects. Using 1000 resamples of the data, the bootstrap method results in 95\% bias-corrected confidence intervals for these effects. We checked whether the mediation process was moderated by digital transformation.

Several models were analysed using a two-step process, starting with the measurement model and moving on to the mediation model. The results of common method variance tests will be provided before we discuss the mediation and measurement model results.

To evaluate the reliability of the sample, first common method variance was assessed. Variance that is attributed to the selected measurement methods is known as common method variance [76]. The same method may have been used to measure two or more constructs, which can lead to an inflated or deflated correlation between constructs [77]. The existence of common method variance was tested by Harman's single factor test, by using un-rotated factor solution. The first factor accounted for only $28.69 \%$ of total variance (less than $50 \%$ ) and the first 5 factors accounted for $72,25 \%$; therefore, there is no common method bias. Additionally, we based questions on facts and emphasized that we would maintain confidentiality of the answers gathered. Before publishing the questionnaire, we asked some entrepreneurs and less digitalization-oriented colleagues whether terms used were clear and easily understandable. We also checked on correlation for common method bias and found that no measurement has higher than 0.8 correlation (Pearson correlation and two-tailed distribution) [78,79].

To test sampling adequacy, Kaiser-Meyer-Olkin measure was applied, and the result was 0.864 , which is above 0.5 , therefore further tests can be implemented. In addition, Bartlett's test of sphericity is significant with $p$ value less than 0.000 .

Communalities extracted were above 0.5 , which was a good result (except for the measure of $\mathrm{dt}$ _jobs, where communality extracted was 0.476 ). The factors were also loaded in a pattern matrix based on constructs.

A convergent validity test and a discriminant validity test were conducted. When one measure of a construct is highly correlated with another measure, estimating the same construct, it is called convergent validity [80]. Discriminant validity is a test to ensure that a construct measure represents phenomena of interest in a structural equation model, which other measures cannot represent $[81,82]$. Because all constructs were modelled reflectively, the variance in the indicators should be high [80]. A convergent validity assessment was conducted using the indicator reliability (outer loadings) and average variance extracted (AVE) from the data, as well as the composite reliability (CR). All indicators had factorial loadings larger than 0.4 , meaning that all factors are important for the construct. Convergent validity was confirmed because all AVE values were larger than $0.5[81,83]$. In addition, the $C R$ values were larger than 0.7 , which confirms reliable measurements. (see Table 3). Comparing the square root of the AVE values with the correlations of latent variables was used to test discriminant validity. [80,84].

Table 3. A convergent validity assessment

\begin{tabular}{ccccc}
\hline Construct & Indicators & $\begin{array}{c}\text { Factorial load- } \\
\text { ing }\end{array}$ & $\begin{array}{c}\text { Average variance ex- } \\
\text { tracted }\end{array}$ & $\begin{array}{c}\text { Composite } \\
\text { reliability }\end{array}$ \\
\hline Digital orientation & do_bd & 0.849 & 0.683 & 0.915
\end{tabular}




\begin{tabular}{ccccc} 
& do_iot & 0.750 & & \\
& do_AI & 0.876 & & \\
& do_ro & 0.834 & & \\
& do_bc & 0.817 & & \\
\hline Digital capability & dc_so & 0.735 & & \\
& dc_ma & 0.809 & & \\
& dc_ws & 0.757 & & \\
& dc_pr & 0.771 & & \\
& dc_da & 0.847 & 0.6013 \\
Digital transfor- & dc_le & 0.798 & & \\
mation & dc_in & 0.760 & & \\
& dt_op & 0.819 & & \\
& Dt_bm & 0.856 & & \\
& Dt_cl & 0.803 & & \\
Dt_fu & 0.913 & & \\
\hline Revenue and busi- & Dt_jo & 0.608 & & \\
ness model complex- & FV & 0.732 & & \\
ity & & & & \\
& BM & 0.834 & & \\
\hline
\end{tabular}

Source: authors' calculated

As for all constructs variance extracted was higher than correlation squared for other constructs, discriminant validity of constructs was confirmed (see Table 4).

Table 4. Component Correlation Matrix Squared

\begin{tabular}{ccccc}
\hline Component & $\mathbf{1}$ & $\mathbf{2}$ & $\mathbf{3}$ & $\mathbf{4}$ \\
\hline 1 & & 0.079 & 0.007 & 0.009 \\
2 & 0.079 & & 0.002 & 0.060 \\
3 & 0.007 & 0.002 & & 0.009 \\
4 & 0.009 & 0.060 & 0.009 & \\
\hline
\end{tabular}

Notes: Extraction Method: Principal Component Analysis. Rotation Method: Promax with Kaiser Normalization.

Source: authors' calculated

\subsection{Mediation model results}

As all prerequisites for estimation of the model had been met, the mediation model was being developed using PROCESS by A.Hayes [21]. As this tool allows to differentiate between direct and mediated effects, additional results were presented in Table 5. As results suggest, digital orientation has a positive effect on digital transformation ( $\beta=0.0865$, $\mathrm{p}=0.1$ ), therefore $\mathrm{H} 1$ can be confirmed, but effect is weak. Within social sciences and abstract terms like digital transformation, and results that use survey data as inputs thresholds can be relaxed to accommodate less diverse and disperse construct variables [85]. Digital capability has a positive effect on digital transformation $(\beta=0.062, p<0.1)$ and H2 can be confirmed. However, it was found that digital orientation has a positive and direct effect on revenue $(\beta=0.094, p<0.01)$. Also, H3 is confirmed $(\beta=0.0937, \mathrm{p}<0.01)$, implying that digital transformation mediates the effect of digital orientation on revenue. This shows that firms must not only increase their digital orientation, but also perform digital transformation to increase their revenue and fulfil the ultimate goal of the owners (increase the owners' wellbeing). $\mathrm{H} 4$ is also confirmed $(\beta=0.0387, \mathrm{p}<0.05)$, meaning there is a digital orientation effect on the business model complexity, which is mediated by digital transformation. H5 is also confirmed $(\beta=0.032, \mathrm{p}<0.01)$, signifying that there is a positive effect of digital capability on revenue, and it is mediated by digital transformation. However, 
digital capability also directly has a positive effect on revenue $(\beta=0.0319, \mathrm{p}<0.01)$. Interesting results show $\mathrm{H} 6$ testing ( $\beta=-0.004$, not significant), as this hypothesis is rejected, however, digital transformation itself has a positive effect on the business model complexity $(\beta=0.0661, p<0.01)$. The conceptual results are presented in Figure 1.

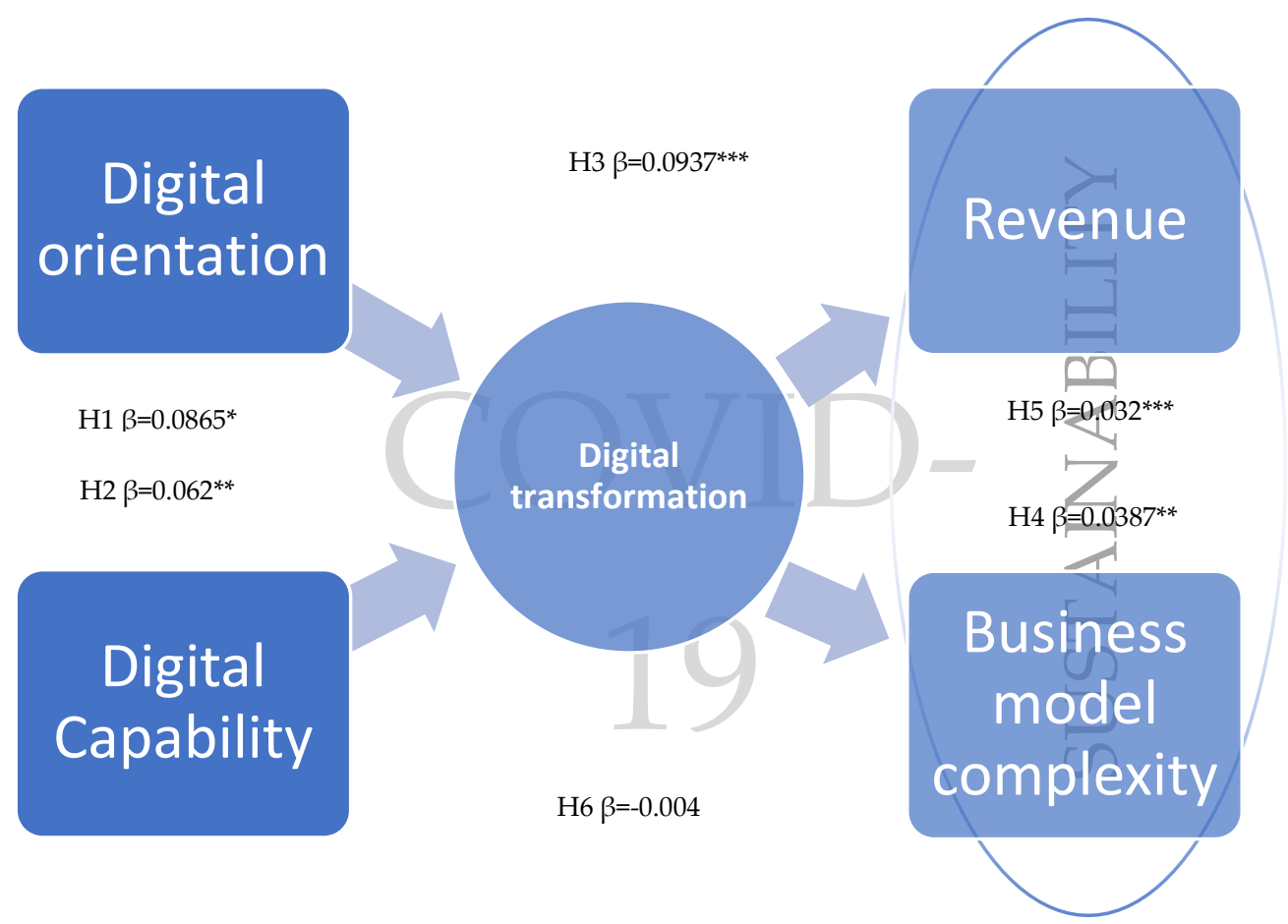

Figure 1. Structural model

Notes: * significant at $\mathrm{p} \leq 0.1,{ }^{* *}$ significant at $\mathrm{p} \leq 0.05,{ }^{* * *}$ significant at $\mathrm{p} \leq 0.01$

Table 5. Hypotheses testing results

\begin{tabular}{|c|c|c|c|c|c|c|c|}
\hline Hypothesis & $\begin{array}{c}\text { Coeffi- } \\
\text { cient }\end{array}$ & $\begin{array}{l}\text { Standard } \\
\text { error }\end{array}$ & $\begin{array}{c}\text { t- } \\
\text { value }\end{array}$ & $\begin{array}{c}p \\
\text { value }\end{array}$ & LLCI & ULCI & Decision \\
\hline $\begin{array}{l}\text { H1. Digital orientation has a } \\
\text { positive effect on digital } \\
\text { transformation of SMEs, } \\
\text { fuelled by COVID-19. }\end{array}$ & 0.0865 & 0.0532 & 1.6266 & 0.1001 & -0.0183 & 0.1913 & Confirmed \\
\hline $\begin{array}{l}\text { H2. Digital capability has a } \\
\text { positive effect on digital } \\
\text { transformation of SMEs, } \\
\text { fuelled by COVID-19. }\end{array}$ & 0.062 & 0.0322 & 1.9253 & 0.0554 & -0.0014 & 0.1255 & Confirmed \\
\hline $\begin{array}{l}\text { H3. Digital transformation } \\
\text { mediates the effect of digital } \\
\text { orientation on revenue of } \\
\text { SMEs, fuelled by COVID- } 19 \text {. }\end{array}$ & 0.0937 & 0.0137 & 6.8468 & 0.000 & 0.0668 & 0.1207 & Confirmed \\
\hline $\begin{array}{l}\text { Digital orientation (DO) has a } \\
\text { positive direct effect on reve- } \\
\text { nue }\end{array}$ & 0.094 & 0.0138 & 6.817 & 0.000 & 0.0669 & 0.1212 & $\begin{array}{l}\text { DO affects } \\
\text { revenue }\end{array}$ \\
\hline $\begin{array}{l}\text { Digital transformation }(\mathrm{DT}) \\
\text { has a positive direct effect on } \\
\text { revenue }\end{array}$ & -0.0033 & 0.0165 & -0.1975 & 0.8436 & -0.0358 & 0.0293 & $\begin{array}{l}\text { DT does not } \\
\text { affect revenue }\end{array}$ \\
\hline $\begin{array}{l}\text { H4. Digital transformation } \\
\text { mediates the effect of digital } \\
\text { orientation on business model }\end{array}$ & 0.0387 & 0.0204 & 1.8967 & 0.0591 & -0.0015 & 0.079 & Confirmed \\
\hline
\end{tabular}




\begin{tabular}{|c|c|c|c|c|c|c|c|}
\hline $\begin{array}{l}\text { complexity of SMEs, fuelled } \\
\text { by COVID-19. }\end{array}$ & & & & & & & \\
\hline $\begin{array}{l}\text { Digital transformation has a } \\
\text { positive effect on business } \\
\text { model complexity (BM) }\end{array}$ & 0.06 & 0.0243 & 2.4673 & 0.0143 & 0.0121 & 0.1079 & DT affects BM \\
\hline $\begin{array}{l}\text { H5. Digital transformation } \\
\text { mediates the effect of digital } \\
\text { capability on revenue of } \\
\text { SMEs, fuelled by COVID- } 19 .\end{array}$ & 0.032 & 0.0088 & 3.6181 & 0.0004 & 0.0146 & 0.0494 & Confirmed \\
\hline $\begin{array}{l}\text { Digital capability (DT) has a } \\
\text { positive direct effect on reve- } \\
\text { nue }\end{array}$ & 0.0319 & 0.0089 & 3.5787 & 0.0004 & 0.0144 & 0.0495 & $\begin{array}{l}\text { DC affects } \\
\text { revenue di- } \\
\text { rectly }\end{array}$ \\
\hline $\begin{array}{l}\text { H6. Digital transformation } \\
\text { mediates the effect of digital } \\
\text { capability on business model } \\
\text { complexity of SMEs, fuelled } \\
\text { by COVID-19. }\end{array}$ & -0.004 & 0.0125 & -0.3244 & 0.7459 & -0.0286 & 0.0205 & $\begin{array}{l}\text { Not con- } \\
\text { firmed }\end{array}$ \\
\hline $\begin{array}{l}\text { Digital capability has a posi- } \\
\text { tive effect on business model } \\
\text { complexity }\end{array}$ & -0.0082 & 0.0124 & -0.6564 & 0.5122 & -0.0326 & 0.0163 & $\begin{array}{l}\text { DC does not } \\
\text { affect BM }\end{array}$ \\
\hline $\begin{array}{l}\text { Digital transformation has a } \\
\text { positive effect on business } \\
\text { model complexity }\end{array}$ & 0.0661 & 0.0245 & 2.7006 & 0.0074 & 0.0179 & 0.1144 & $\begin{array}{l}\text { Digital trans- } \\
\text { formation di- } \\
\text { rectly affects } \\
\text { BM }\end{array}$ \\
\hline
\end{tabular}

Source: authors' calculated

\section{Theoretical contributions and practical implications}

Theoretical contribution of our research addresses four major building blocks of theory. These are what? When? How and Why?

What? In this study, we explain how the phenomenon of digital transformation plays a mediating role of digital orientation and digital capability on the economic sustainability of SMEs.

When? In our study, COVID-19 was viewed as a framework of digital transformation for SMEs. COVID-19 has recently triggered another crisis; thus, scientists, entrepreneurs and people in the research industry are faced with an entirely new global quest with economic and social impact [35]. Covid-19 is a new, unexplored framework that has spurred the digital transformation of companies. According to McKinsey's report Covid-19 has accelerated overall digital adoption by three to seven years in a matter of months [12].

How? Digital orientation and digital capability have direct positive effects on digital transformation; higher levels of digital orientation and capability, mediated by digital transformation, lead to higher revenue; as well as a more complex business model in the case of digital orientation. At the same time, higher levels of digital orientation and capability mediated by digital transformation contribute to greater economic sustainability of SMEs.

Why? On the digital journey, companies will be faced with several resource challenges, including the need to commit new and sometimes very substantial resources to the company, employees, and customers. To explore the impact of digital transformation on economic sustainability of SMEs during COVID-19, we draw on two specific perspectives of resource-based theory: resource orchestration and dynamic management capabilities approaches. Both theories as extensions of resource-based theory have helped to develop the concepts of digital orientation and digital capability that are mediated by digital transformation. Digital transformation provides SMEs with strategic directions to develop and implement specific digital transformation strategies and select appropriate digitalization initiatives to ensure their sustainable journey. 
The practical implications of this research can be directed mainly at policymakers and managers of SMEs. Extensive scientific research proves that digital transformation does not start by itself, in different sectors of the national economy there are various triggers that launch this process. Since our research shows the relationship between digital orientation, digital capability and digital transformation, its practical value for policymakers lies in the possibility of applying the results of this study to initiate the process of digital transformation among SMEs via strengthening their digital orientation and capabilities. Despite the positive trend towards digitalization in general, human capital and digital integration in many SMEs remain relatively low. Significant number of SMEs still are far away from the idea of digital transformation; hence triggering is essential. This study not only provides policymakers with the answer to the question what processes should be supported, but also introduces the rationale why, including the context of revenue, complexity of business model and sustainability.

Recommendations for SME managers to innovate and build sustainability include the need to harness the benefits of digital transformation for SMEs. SMEs should use more cloud computing and artificial intelligence, which provide a wide range of creative solutions for different industries, especially given their recent higher availability. By focusing on digital orientation and digital capability, SMEs investing in digital technologies can increase their sustainability, and our findings can be extremely useful in raising the awareness of SMEs about various aspects of their digital orientation and capability.

The results of this study can be useful for SMEs managers in understanding the imperative of investing in specific areas improving digital orientation and digital capabilities. Practical implementation for SMEs managers relates to changing their perception of enhanced digital orientation and digital capabilities as an opportunity for survival and a tribute to fashion to considering the investments in extending digital orientation and digital capabilities as an opportunity that changes the level of revenue, as well as the direction and potential of future development carried out in the most sustainable manner.

\section{Discussion and Conclusions}

In the past few years, our world has been leaning more and more towards the digital realm, mostly because of a younger, more technologically dependent generation. Digital transformation, according to politicians and academics, is a critical aspect in the development and modernization of businesses and economies in general. Thus, there are benefits for both-industries and society. Digital transformation is not only an imperative, but also an opportunity for countries to increase their economic, social and environmental benefits. In addition, investing in digital technologies and capacities, together with a circular economy, can help create jobs and growth in the global race to recovery.

In this study we explore the role of digital transformation, fostered by COVID-19, and the way it can contribute to the sustainability of SMEs. To achieve the study's purpose a new concept was created.

Considering the need of digital transformation in resource management, the conceptual framework was developed on a literature review based on two specific perspectives of resource-based theory: resource orchestration and dynamic managerial capabilities theories. The conceptual framework (Figure 1) is examining, first, the effect of digital orientation and digital capability on digital transformation. Next, we check the effect of digital orientation and digital capability on revenue and business model complexity mediated by digital transformation.

The appropriateness of the measurement model has been confirmed by several tests, including the adequacy Kaiser-Meyer-Olkin measure, Bartlett's test, convergent validity and discriminant validity tests, etc. The mediation model was being developed using PROCESS by A. Hayes [21], which made it possible to distinguish between direct and mediated effects of digital transformation on the sustainability of SMEs. The results of the study provide empirical evidence supporting the conceptual model, since almost all hypotheses, except H6, have been confirmed. Even if the effect of digital capability on the business model complexity mediated by digital transformation (H6) wasn't confirmed, 
we found that digital capability has a positive direct effect on digital transformation, and digital transformation also has a positive direct effect on the business model complexity.

This study results show that digital transformation affects not only revenue, but also the complexity of the SME business model. The results of the structural model suggest exactly where future funding (public and private) should be sourced to increase the performance and sustainability of SMEs.

As far as the authors know, there are no other studies on the effect of digital orientation and digital capability on digital transformation and its mediating impact on revenue and business model complexity, fostered by COVID-19, but several studies are investigating the relationships between digital orientation and digital capability on digital innovation [31-34]. We used these findings to support our study's findings, as digital innovation can drive digital transformation $[86,87]$.

We found that digital orientation has a positive effect on digital transformation with a $90 \%$ confidence interval (H1). Our finding is consistent with the findings of Khin and Ho [32], who found that digital orientation has a significant beneficial impact on digital innovation, as well as Yang et al. [62], who found that technological orientation has a positive impact on innovative products. The mediation effect of digital transformation from digital orientation on revenue and business model complexity (H3 and H4) was also confirmed. Ardito et al. [34] study results demonstrate that digital and environmental orientation have a positive direct effect on product and process innovation performance. In accordance with Kindermann et al. [31] the digital orientation idea aids in defining the types of digital resources that must be aligned in order for a company to develop a foundation for improved performance. In addition, according to Kindermann et al. [31], adopting and maintaining a digital orientation can help businesses better handle the strategic challenges that come with the pervasiveness of digital technology.

We confirmed the positive effect of digital capability on digital transformation with a 95\% confidence interval (H2). This is in line with the study results of Khin and Ho [32] that digital capability has a positive effect on digital innovation. The mediation effect of digital transformation from digital capability on revenue $(\mathrm{H} 5)$ was also confirmed. Lenka et al. [28] identified and explained how digitalization capabilities enable value co-creation with customers through perceptive and responsive mechanisms. Verhoef et al. [51] posited that digital transformation requires specific organizational structures and bears consequences for the metrics used to calibrate performance. Yasa et al. [33] claim that digital innovations enhance business performance in positive and significant ways, and that digital innovations facilitate the impact of digital capabilities on business performance. We found statistically insignificant mediating effect of digital transformation from digital capability on the business model complexity (H6). In addition, we cannot confirm that digital capability has a direct positive effect on business model complexity. However, we found statistically significant direct effects of digital capability on digital transformation and of digital transformation on business model complexity. Khin and Ho [32] assert that if a company is able to improve digital capabilities in managing its digital technology, it has a higher possibility to develop innovative digital solutions that will later improve the company's business performance. In addition, Kindermann et al. [31] describe digital technology scope as the collection of digital technologies that enable a company to achieve strategic growth.

Priyono et al. [5] studied how SMEs are adapting to the effects of COVID-19 pandemic, using digital technologies to assist businesses in transforming their business models, and found that degrees of digital transformation vary according to the context of the firm.

The main findings of our study are that digital orientation and digital capability have direct positive effects on digital transformation; higher levels of digital orientation and capability, mediated by digital transformation, lead to higher revenue; as well as a more complex business model in the case of digital orientation. Given that we are examining the economic sustainability of SMEs through the lens of a business model, this allows us to conclude that higher levels of digital orientation and capability, mediated by digital 
transformation, contribute to greater economic sustainability of SMEs. Even if we cannot confirm that higher digital capability, mediated by digital transformation, leads to a more complex business model, we found statistically significant direct effects from digital capability to digital transformation and from digital transformation to business model complexity. In addition, we found that digital orientation and digital capability have a direct positive effect on revenue, while no direct positive effect of digital transformation on revenue has been confirmed.

SMEs are best positioned to fully digitalize the economy due to their systemic power. Other companies benefit from these digital enterprises, which provide technological solutions, such as software, artificial intelligence, blockchain, and the Internet of Things (IoT). Currently, digital transformation is one of the most widely supported processes. Our findings provide policymakers and investors with valuable information about the most significant areas of initiatives, and if digital journey is maintained by public investments, policymakers can achieve wider goal, that is not only to strengthen digital orientation and capabilities of SMEs and optimize their way of digital transformation, but also make digital transformation take place in a sustainable manner and support the environmental goals of the Green Deal and the Circular Economy Action Plan.

Our research has some limitations. First, while the response rate to our study is acceptable, the survey respondents constitute a part of Latvian SMEs. In future studies of the impact of digital transformation on the sustainability of SMEs, it would be useful to include SMEs from other countries. Furthermore, we concentrate primarily on supplyside factors of SMEs' digital transformation. To better understand the drivers of digital transformation in SMEs, it is also necessary to examine the demand side, such as consumers' digital skills, distribution channels and socially responsible business models.

\begin{abstract}
Author Contributions: Conceptualization, R.R.-A., K.P. and L.B.; methodology, R.R.-A. and K.P.; formal analysis, R.R.-A. and K.P.; investigation, R.R.-A. and K.P.; data curation, R.R.-A.; writingoriginal draft preparation, R.R.-A., K.P. and L.B.; writing-review and editing, R.R.-A. and K.P.; visualization, R.R.-A. and L.B. All authors have read and agreed to the published version of the manuscript.
\end{abstract}

Funding: This research was funded by LATVIAN COUNCIL OF SCIENCE, grant number LZP2020/2-0061, project DigiSMEs.

Data Availability Statement: Data is available from authors upon reasonable request.

Acknowledgments: We would like to thank all the companies who took part in the survey.

Conflicts of Interest: The authors declare no conflict of interest.

References

1. OECD The Digital Transformation of SMEs; OECD Studies on SMEs and Entrepreneurship; OECD, 2021; ISBN 97892-64-39245-8.

2. European Investment Bank Digitalisation in Europe 2020-2021: Evidence from the EIB Investment Survey. 2021, 98, doi:DOI 10.2867/1363.

3. European Investment Bank EIB Investment Report 2020/2021: Building a Smart and Green Europe in the COVID-19 Era; European Investment Bank, 2021; ISBN 978-92-861-4811-8.

4. OECD OECD SME and Entrepreneurship Outlook 2019; OECD, 2019; ISBN 978-92-64-37480-5.

5. Priyono, A.; Moin, A.; Putri, V.N.A.O. Identifying Digital Transformation Paths in the Business Model of SMEs during the COVID-19 Pandemic. JOItmC 2020, 6, 104, doi:10.3390/joitmc6040104.

6. Industry 4.0 for SMEs: Challenges, Opportunities and Requirements; Matt, D.T., Modrák, V., Zsifkovits, H., Eds.; Springer International Publishing: Cham, 2020; ISBN 978-3-030-25424-7.

7. Kotarba, M. Measuring Digitalization - Key Metrics. Foundations of Management 2017, 9, 123-138, doi:10.1515/fman2017-0010. 
8. Bullini Orlandi, L. Organizational Capabilities in the Digital Era: Reframing Strategic Orientation. Journal of Innovation \& Knowledge 2016, 1, 156-161, doi:10.1016/j.jik.2016.01.002.

9. The London School of Economics and Political Science; Kallinikos, J.; Aaltonen, A.; Hanken School of Economics; Marton, A.; Copenhagen Business School The Ambivalent Ontology of Digital Artifacts. MISQ 2013, 37, 357-370, doi:10.25300/MISQ/2013/37.2.02.

10. Gregurec, I.; Tomičić Furjan, M.; Tomičić-Pupek, K. The Impact of COVID-19 on Sustainable Business Models in SMEs. Sustainability 2021, 13, 1098, doi:10.3390/su13031098.

11. Checchinato, F.; Hinterhuber, A.; Vescovi, T. The Key Challenges of Digital Transformation Available online: https://www.routledge.com/blog/article/the-key-challenges-of-digital-transformation (accessed on 20 September 2021).

12. McKinsey Digital Strategy in the Postpandemic Era Available online: https://www.mckinsey.com/businessfunctions/mckinsey-digital/our-insights/the-new-digital-edge-rethinking-strategy-for-the-postpandemic-era (accessed on 30 December 2021).

13. Pham, D.C.; Do, T.N.A.; Doan, T.N.; Nguyen, T.X.H.; Pham, T.K.Y. The Impact of Sustainability Practices on Financial Performance: Empirical Evidence from Sweden. Cogent Business \& Management 2021, 8, 1912526, doi:10.1080/23311975.2021.1912526.

14. Frey, J. How Digital Transformation and Sustainability Can Flourish Available online: https://www.weforum.org/agenda/2021/03/here-s-how-digital-transformation-and-sustainability-can-flourishtogether/ (accessed on 2 November 2021).

15. WEF Bridging Digital and Environmental Goals: A Framework for Business Action; 2021; p. 27;.

16. Paula, D. Strengthening the Green Deal in Latvia: What Could We Expect from Electrical Mobility? Available online: https://www.macroeconomics.lv/strengthening-green-deal-latvia-what-could-we-expect-electrical-mobility (accessed on 13 November 2021).

17. European Commission The Digital Economy and Society Index (DESI) 2021 Latvia; 2021; p. 18;.

18. EIB Group Survey on Investment and Investment Finance 2020. European Union Overview. 44.

19. Abel-Koch, J.; Al Obaidi, L.; El Kasmi, S.; Acevedo, M.F.; Morin, L.; Topczewska, A. Report The Challenges Facing European SMEs 2019; European SME survey 2019; 2019; p. 80;.

20. Shkapars, A. Liela dạ̣a Baltijas mazo un vidējo uzṇēmumu nesteidzas digitalizēt savu darbību. Delfi 2020.

21. Hayes, A.F. Introduction to Mediation, Moderation, and Conditional Process Analysis, Third Edition: A Regression-Based Approach; Third edition.; The Guilford Press: New York, NY, 2022; ISBN 978-1-4625-4903-0.

22. Sebastian, I.M.; Moloney, K.G.; Ross, J.W.; Fonstad, N.O.; Beath, C.; Mocker, M. How Big Old Companies Navigate Digital Transformation. MIS Quarterly Executive 2017, 16, 197-213.

23. Conway, G. A Dynamic Capability Approach to Digital Transformation - a Focus on Key Foundational Themes.

24. Chonsawat, N.; Sopadang, A. Defining SMEs' 4.0 Readiness Indicators. Applied Sciences 2020, 10, 8998, doi:10.3390/app10248998.

25. DIGIBEST REGIONAL STUDY ON THE STATE OF DIGITAL TRANSFORMATION AND ITS IMPACT ON THE REGIONAL BUSINESSES IN LATVIA Available online: https://www.interregeurope.eu/digibest/ (accessed on 17 September 2021).

26. Truant, E.; Broccardo, L.; Dana, L.-P. Digitalisation Boosts Company Performance: An Overview of Italian Listed Companies. Technological Forecasting and Social Change 2021, 173, 121173, doi:10.1016/j.techfore.2021.121173.

27. Adrodegari, F.; Pashou, T.; Saccani, N. Business Model Innovation: Process and Tools for Service Transformation of Industrial Firms. Procedia CIRP 2017, 64, 103-108, doi:10.1016/j.procir.2017.03.056.

28. Lenka, S.; Parida, V.; Wincent, J. Digitalization Capabilities as Enablers of Value Co-Creation in Servitizing Firms: DIGITALIZATION CAPABILITIES. Psychol. Mark. 2017, 34, 92-100, doi:10.1002/mar.20975. 
29. Kuzmina-Merlino, I.; Saksonova, S. The Knowledge and Competencies Required for the Fintech Sector. In Proceedings of the New Challenges of Economic and Business Development - 2018: Productivity and Economic Growth; Univ Latvia: Riga, 2018; pp. 387-395.

30. Kohtamäki, M.; Parida, V.; Patel, P.C.; Gebauer, H. The Relationship between Digitalization and Servitization: The Role of Servitization in Capturing the Financial Potential of Digitalization. Technological Forecasting and Social Change 2020, 151, 119804, doi:10.1016/j.techfore.2019.119804.

31. Kindermann, B.; Beutel, S.; Garcia de Lomana, G.; Strese, S.; Bendig, D.; Brettel, M. Digital Orientation: Conceptualization and Operationalization of a New Strategic Orientation. European Management Journal 2020, doi:10.1016/j.emj.2020.10.009.

32. Khin, S.; Ho, T.C. Digital Technology, Digital Capability and Organizational Performance: A Mediating Role of Digital Innovation. IJIS 2019, 11, 177-195, doi:10.1108/IJIS-08-2018-0083.

33. Yasa, N.N.K.; Ekawati, N.W.; Rahmayanti, P.L.D. THE ROLE OF DIGITAL INNOVATION IN MEDIATING DIGITAL CAPABILITY ON BUSINESS PERFORMANCE. European Journal of Management and Marketing Studies 2019, 4, doi:10.5281/zenodo.3483780.

34. Ardito, L.; Raby, S.; Albino, V.; Bertoldi, B. The Duality of Digital and Environmental Orientations in the Context of SMEs: Implications for Innovation Performance. Journal of Business Research 2021, 123, 44-56, doi:10.1016/j.jbusres.2020.09.022.

35. Ratten, V. Coronavirus (Covid-19) and Entrepreneurship: Changing Life and Work Landscape. Journal of Small Business E Entrepreneurship 2020, 32, 503-516, doi:10.1080/08276331.2020.1790167.

36. MacKenzie, S.B.; Podsakoff, P.M.; Podsakoff, N.P. Construct Measurement and Validation Procedures in MIS and Behavioral Research: Integrating New and Existing Techniques. MIS Quarterly 2011, 35, 293-334, doi:10.2307/23044045.

37. Green, R.; Agarwal, R.; Logue, D. Innovation. In International Encyclopedia of the Social E Behavioral Sciences (Second Edition); Wright, J.D., Ed.; Elsevier: Oxford, 2015; pp. 145-151 ISBN 978-0-08-097087-5.

38. Badrinarayanan, V.; Ramachandran, I.; Madhavaram, S. Resource Orchestration and Dynamic Managerial Capabilities: Focusing on Sales Managers as Effective Resource Orchestrators. Journal of Personal Selling $\mathcal{E}$ Sales Management 2019, 39, 23-41, doi:10.1080/08853134.2018.1466308.

39. Li, M.; Jia, S. Resource Orchestration for Innovation: The Dual Role of Information Technology. Technology Analysis $\mathcal{E}$ Strategic Management 2018, 30, 1136-1147, doi:10.1080/09537325.2018.1443438.

40. Wójcik, P. Exploring Links Between Dynamic Capabilities Perspective and Resource-Based View: A Literature Overview. International Journal of Management and Economics 2015, 45, 83-107, doi:10.1515/ijme-2015-0017.

41. Mubarak, M.F.; Petraite, M. Industry 4.0 Technologies, Digital Trust and Technological Orientation: What Matters in Open Innovation? Technological Forecasting and Social Change 2020, 161, 120332, doi:10.1016/j.techfore.2020.120332.

42. Pelletier, C.; Raymond, L. Orchestrating the Digital Transformation Process through a 'Strategy-as-Practice' Lens: A Revelatory Case Study.; 2020.

43. Ziółkowska, M.J. Digital Transformation and Marketing Activities in Small and Medium-Sized Enterprises. Sustainability 2021, 13, 2512, doi:10.3390/su13052512.

44. Laidroo, L.; Koroleva, E.; Kliber, A.; Rupeika-Apoga, R.; Grigaliuniene, Z. Business Models of FinTechs - Difference in Similarity? Electronic Commerce Research and Applications 2021, 46, 101034, doi:10.1016/j.elerap.2021.101034.

45. Malak, H.A. Digitization vs Digitalization: What's The Difference? Available online: https://theecmconsultant.com/digitization-vs-digitalization/ (accessed on 13 September 2021).

46. Fakhar Manesh, M.; Pellegrini, M.M.; Marzi, G.; Dabic, M. Knowledge Management in the Fourth Industrial Revolution: Mapping the Literature and Scoping Future Avenues. IEEE Transactions on Engineering Management 2021, 68, 289-300, doi:10.1109/TEM.2019.2963489. 
47. Rupeika-Apoga, R.; Nedovis, R. The Foreign Exchange Exposure of Domestic Companies in Eurozone: Case of the Baltic States. ERSJ 2016, XIX, 165-178, doi:10.35808/ersj/512.

48. The Enterprisers Project What Is Digital Transformation? Available online: https://enterprisersproject.com/what-isdigital-transformation (accessed on 12 September 2021).

49. Rupeika-Apoga, R.; Solovjova, I. Profiles of SMEs as Borrowers: Case of Latvia. Contemporary Studies in Economic and Financial Analysis 2016, 98, 63-76, doi:10.1108/S1569-375920160000098005.

50. Newbert, S.L. Empirical Research on the Resource-Based View of the Firm: An Assessment and Suggestions for Future Research. Strat. Mgmt. J. 2007, 28, 121-146, doi:10.1002/smj.573.

51. Verhoef, P.C.; Broekhuizen, T.; Bart, Y.; Bhattacharya, A.; Qi Dong, J.; Fabian, N.; Haenlein, M. Digital Transformation: A Multidisciplinary Reflection and Research Agenda. Journal of Business Research 2021, 122, 889901, doi:10.1016/j.jbusres.2019.09.022.

52. McKinsey \& Company Global Surveys of Consumer Sentiment during the Coronavirus Crisis Available online: https://www.mckinsey.com/business-functions/marketing-and-sales/our-insights/global-surveys-of-consumersentiment-during-the-coronavirus-crisis (accessed on 21 October 2021).

53. O'Cass, A.; Ngo, L.V.; Siahtiri, V. Marketing Resource-Capability Complementarity and Firm Performance in B2B Firms. Journal of Business \& Industrial Marketing 2015, 30, 194-207, doi:10.1108/JBIM-05-2012-0087.

54. Daub, M.; Wiesinger, A. Acquiring the Capabilities You Need to Go Digital Available online: https://www.mckinsey.com/business-functions/mckinsey-digital/our-insights/acquiring-the-capabilities-youneed-to-go-digital (accessed on 21 October 2021).

55. Giudice, M.; Peruta, M.R.D. The Impact of IT-Based Knowledge Management Systems on Internal Venturing and Innovation: A Structural Equation Modeling Approach to Corporate Performance. J. Knowl. Manag. 2016, doi:10.1108/JKM-07-2015-0257.

56. Denicolai, S.; Zucchella, A.; Magnani, G. Internationalization, Digitalization, and Sustainability: Are SMEs Ready? A Survey on Synergies and Substituting Effects among Growth Paths. Technological Forecasting and Social Change 2021, 166, 120650, doi:10.1016/j.techfore.2021.120650.

57. Wiech, M.; Boffelli, A.; Elbe, C.; Carminati, P.; Friedli, T.; Kalchschmidt, M. Implementation of Big Data Analytics and Manufacturing Execution Systems: An Empirical Analysis in German-Speaking Countries. Production Planning \& Control 2020, 1-16, doi:10.1080/09537287.2020.1810766.

58. Martín-Peña, M.-L.; Sánchez-López, J.-M.; Díaz-Garrido, E. Servitization and Digitalization in Manufacturing: The Influence on Firm Performance. JBIM 2019, 35, 564-574, doi:10.1108/JBIM-12-2018-0400.

59. Saksonova, S.; Kuzmina-Merlino, I. Cryptocurrency as an Investment Instrument in a Modern Financial Market. SUJES 2019, 35, 269-282, doi:10.21638/spbu05.2019.205.

60. Osterwalder, A.; Pigneur, Y. Business Model Generation A Handbook for Visionaries, Game Changers, and Challengers; 2010; ISBN 978-1-118-65640-2.

61. Schaltegger, S.; Hansen, E.G.; Lüdeke-Freund, F. Business Models for Sustainability: Origins, Present Research, and Future Avenues. Organization \& Environment 2016, 29, 3-10, doi:10.1177/1086026615599806.

62. Yang, S.; Lu, Y.; Gupta, S.; Cao, Y.; Zhang, R. Mobile Payment Services Adoption across Time: An Empirical Study of the Effects of Behavioral Beliefs, Social Influences, and Personal Traits. Computers in Human Behavior 2012, 28, 129-142, doi:10.1016/j.chb.2011.08.019.

63. Cenamor, J.; Rönnberg Sjödin, D.; Parida, V. Adopting a Platform Approach in Servitization: Leveraging the Value of Digitalization. International Journal of Production Economics 2017, 192, 54-65, doi:10.1016/j.ijpe.2016.12.033.

64. LUISS Guido Carli University A DIGITALISATION PROJECT OUTPUT; 2019; p. 89;.

65. European Investment Bank Digitalisation in Europe 2020-2021: Evidence from the EIB Investment Survey; European Investment Bank, 2021; ISBN 978-92-861-5041-8. 
66. Zaidi, S.H.; Rupeika-Apoga, R. Liquidity Synchronization, Its Determinants and Outcomes under Economic Growth Volatility: Evidence from Emerging Asian Economies. Risks 2021, 9, 43, doi:10.3390/risks9020043.

67. Al-Ansari, Y.; Altalib, M.; Sardoh, M. Technology Orientation, Innovation and Business Performance: A Study of Dubai SMEs. ITMR 2013, 3, 1, doi:10.2991/itmr.2013.3.1.1.

68. Zhang, J.; Long, J.; von Schaewen, A.M.E. How Does Digital Transformation Improve Organizational Resilience? Findings from PLS-SEM and FsQCA. Sustainability 2021, 13, 11487, doi:10.3390/su132011487.

69. Youssef, C.; Lebdaoui, H. The Impact of Digital Transformation on SMEs Organizational Performance: The Mediating Effect of Digital Innovation.; Dublin, Ireland, December 62020.

70. European Commission Commission Recommendation of 6 May 2003 Concerning the Definition of Micro, Small and Medium-Sized Enterprises (Text with EEA Relevance) (Notified under Document Number C(2003) 1422); 2003;

71. Bank of Latvia Financial Stability Report Available online: https://www.bank.lv/en/publications-r/financialstability-report (accessed on 15 November 2021).

72. Smith, W.K.; Binns, A.; Tushman, M.L. Complex Business Models: Managing Strategic Paradoxes Simultaneously. Long Range Planning 2010, 43, 448-461, doi:10.1016/j.lrp.2009.12.003.

73. Morakanyane, R.; Grace, A.; O’Reilly, P. Conceptualizing Digital Transformation in Business Organizations: A Systematic Review of Literature. In Proceedings of the Digital Transformation - From Connecting Things to Transforming Our Lives; University of Maribor Press, June 2017; pp. 427-443.

74. Osmundsen, K.; Iden, J.; Bygstad, B. Digital Transformation: Drivers, Success Factors, and Implications. In Proceedings of the MCIS; 2018.

75. Liu, X.; Huang, Q.; Dou, J.; Zhao, X. The Impact of Informal Social Interaction on Innovation Capability in the Context of Buyer-Supplier Dyads Available online: http://ir.ceibs.edu/ (accessed on 20 October 2021).

76. Podsakoff, P.M.; MacKenzie, S.B.; Lee, J.-Y.; Podsakoff, N.P. Common Method Biases in Behavioral Research: A Critical Review of the Literature and Recommended Remedies. Journal of Applied Psychology 2003, 88, 879-903, doi:10.1037/0021-9010.88.5.879.

77. Bagozzi, R.P.; Yi, Y. Assessing Method Variance in Multitrait-Multimethod Matrices: The Case of Self-Reported Affect and Perceptions at Work. Journal of Applied Psychology 1990, 75, 547-560, doi:10.1037/0021-9010.75.5.547.

78. Chang, S.-J.; van Witteloostuijn, A.; Eden, L. From the Editors: Common Method Variance in International Business Research. J Int Bus Stud 2010, 41, 178-184, doi:10.1057/jibs.2009.88.

79. Podsakoff, P.M.; MacKenzie, S.B.; Podsakoff, N.P. Sources of Method Bias in Social Science Research and Recommendations on How to Control It. Annu. Rev. Psychol. 2012, 63, 539-569, doi:10.1146/annurev-psych-120710100452.

80. F. Hair Jr, J.; Sarstedt, M.; Hopkins, L.; G. Kuppelwieser, V. Partial Least Squares Structural Equation Modeling (PLS-SEM): An Emerging Tool in Business Research. European Business Review 2014, 26, 106-121, doi:10.1108/EBR10-2013-0128.

81. Multivariate Data Analysis; Hair, J.F., Ed.; 7th ed.; Prentice Hall: Upper Saddle River, NJ, 2010; ISBN 978-0-13-8132637.

82. Hair, J.F.; Hult, G.T.M.; Ringle, C.M.; Sarstedt, M.; Danks, N.P.; Ray, S. Partial Least Squares Structural Equation Modeling (PLS-SEM) Using R: A Workbook; Classroom Companion: Business; Springer International Publishing: Cham, 2021; ISBN 978-3-030-80518-0.

83. Henseler, J.; Ringle, C.M.; Sinkovics, R.R. The Use of Partial Least Squares Path Modeling in International Marketing. In Advances in International Marketing; Sinkovics, R.R., Ghauri, P.N., Eds.; Emerald Group Publishing Limited, 2009; Vol. 20, pp. 277-319 ISBN 978-1-84855-468-9.

84. Fornell, C.; Larcker, D.F. Evaluating Structural Equation Models with Unobservable Variables and Measurement Error. Journal of Marketing Research 1981, 18, 39, doi:10.2307/3151312. 
85. Dahiru, T. P-Value, a True Test of Statistical Significance? A Cautionary Note. Ann. Ibadan Postgrad. Med. 2011, 6, 21-26, doi:10.4314/aipm.v6i1.64038.

86. Hinings, B.; Gegenhuber, T.; Greenwood, R. Digital Innovation and Transformation: An Institutional Perspective. Information and Organization 2018, 28, 52-61, doi:10.1016/j.infoandorg.2018.02.004.

87. Bygstad, B.; Øvrelid, E. Managing Two-Speed Innovation for Digital Transformation. Procedia Computer Science 2021, 181, 119-126, doi:10.1016/j.procs.2021.01.111. 